\title{
Re St Michael Within the Walls, Bath
}

Bath and Wells Consistory Court: Briden Ch, October 2010 Private place of worship - historic chapel - 'interested person'

The chancellor granted a faculty for the removal of pews from an historic chapel which was, in law, a private place of worship but which was open to the public for services. The 18th century chapel formed part of a medieval hospital in Bath which continued to provide sheltered accommodation. In reaching his decision the chancellor took full account of the written views of various members of the public, all of whom lived within Bath and had either worshipped in the chapel or become familiar with it as a place of historic importance. He referred to the dictum of Phillips Ch in Re St Thomas, Lymington' stating that 'all parishioners, regardless of whether or not they claim or manifest any allegiance to the Church, are entitled to be heard as persons having an interest'. He held that such dictum applied with equal force to an historic chapel outside the parochial system, but visited by members of the public, as it did to a parish church. [RA]

doi:10.1017/So956618X11000305

\section{Re Church of the Community of the Resurrection, Mirfield \\ Wakefield Consistory Court: Downes Ch, November 2010 Reordering - monastic church - Bishopsgate questions}

Representatives of the monastic community petitioned for a re-ordering of their church to include the change of certain furniture, the levelling of the floor and the installation of new heating, lighting and sound systems. There had been a number of accidents and disabled brethren were currently unable to join in with the sacramental life of the community. The church had been almost completely abandoned as a monastic centre for worship. The petitioners submitted that the proposals were necessary in order to avoid future accidents and to ensure full access to the church for brethren, pilgrims and visitors. An objector argued that the proposed works should not go ahead, inter alia, because their purpose was to improve the comfort of the brethren and such considerations were improper for monastic brothers. The chancellor applied the Bishopsgate questions and then posed a fourth relevant question applicable to the case of a monastic (as opposed to a parish) church: 'whose need is to be considered?' The chancellor observed that disability discrimination legislation required the needs of both the brethren and the public to be considered. Noting that the pastoral reasons for the proposed changes were overwhelming, the chancellor 
considered the needs of both the brethren and wider worshipping community and granted the faculty. [RA]

doi:10.1017/So956618X11000317

\section{Aguilar and others v Secretary of State for the Home Department Court of Appeal: Sedley, Pitchford and Gross LJJ, December 2010 Immigration rules - foreign spouses - right to family life - proportionality}

Diego Aguilar, aged 20, was refused leave to remain in the UK as a spouse of a UK citizen on the basis that both he and his wife were under the age of 21. The refusal was made under paragraph 277 of the Immigration Rules, which requires both the incoming and the sponsoring spouse to be aged over 21 years before a visa would be granted. Mr Aguilar challenged the legality of the paragraph. The Home Secretary defended it on the basis that it was a proportionate response to the problem of forced marriage. Mr Aguilar's application for judicial review was unsuccessful, and he appealed to the Court of Appeal.

Paragraph 277 was challenged on three bases: first, that the rule was irrational in that its objective had nothing to do with immigration and that it was therefore an abuse of the prerogative power of immigration control to use the rules for that purpose; secondly, that the rule was a disproportionate inhibition on the right to private and family life and on the right to marry under Articles 8 and 12 respectively of the European Convention on Human Rights; and thirdly, that the rule was discriminatory in that it makes an illogical exception in favour of service personnel who may be granted a visa where one party to the marriage is over 18 years of age.

On the basis that about one-third of all forced marriages were thought to include spouses aged 21 and under, the court held that it could not be said that the rule was irrational. The Home Secretary had reached a tenable (but debatable) view that the rule would reduce the incidence of forced marriage in the UK. The court held that paragraph 277 represented a direct interference in common law and Convention rights to marry and to respect for family life. Further, the court held that the paragraph was a disproportionate response to the problem of forced marriage and that that policy imperative was only obliquely, partially and in large part speculatively related to paragraph 277 . The court held that the arguments about discrimination were essentially already addressed in the ruling on proportionality. The appeals were allowed. [RA] 